\title{
First Black Patent: on Dry Cleaning System
}

\author{
Marcio Luis Ferreira Nascimento* \\ Department of Chemical Engineering, Federal University of Bahia, Brazil
}

Submission: January 24, 2018; Published: June 13, 2018

*Corresponding author: Marcio Luis Ferreira Nascimento, Department of Chemical Engineering, Polytechnic School, Federal University of Bahia, Rua Aristides Novis 2, Federação, 40210 - 630 Salvador, BA, Brazil, Email: mlfn@ufba.br

Keywords: Dry scouring clothes; Manual and intellectual; Cleaning and washing; Tailor; Entrepreneur; Inventor and abolitionist

\section{Commentary}

Following 1793 Patent Act and the current American laws, they declared that "the master is the owner of the fruits of the labor of the slave both manual and intellectual". Thus, no slave could patent his own inventions, because if they intended, patents would be considered property of their owner. There are a vast literature on subject [1,2].

However, there was a descendant of slaves who submitted a patent a few decades later, and was able to obtain a grant, under number US 3,306X, published on March 3, 1821 [1]. The required patent had the following title: "Dry Scouring Clothes," about a new method of cleaning and washing that preceded the dry cleaning current system $[3,4]$.

The patentee was Thomas L. Jennings (1791 - 1856), tailor, entrepreneur, inventor and abolitionist, a free man. That was the reason why he obtained exclusive rights and the patent privilege of a new dry cleaning process (Figure 1). However, it was not an easy task, because his request was contested by the fact of being black. Jennings won the case because the law simply was not applicable to him. It was only in 1861 that the American Congress reviewed the rules to extend patent rights to slaves, since the new law understood that the privilege should be granted "only to its one true inventor," even if they were still considered to be a property of someone. It is worth remembering that the US Emancipation Proclamation occurred two years later, on January 1, 1863, by President Abraham Lincoln (1809 - 1865).

As any other patent request, Jennings' demand should surpass the three tests of patentability: novelty, usefulness and non-obviousness. With these items taken into account, and in agreement with the American patent law established on April 10, 1790 , his application was granted, with a twenty year's privilege. Having the right to commercially exploit his invention, he would set prices for others who had interest in his new innovation. And more, with the interesting advantage of legally exclude third parties. There are lots of advertisements of Jennings' innovation as well as other services (Figures 1 \& 2).

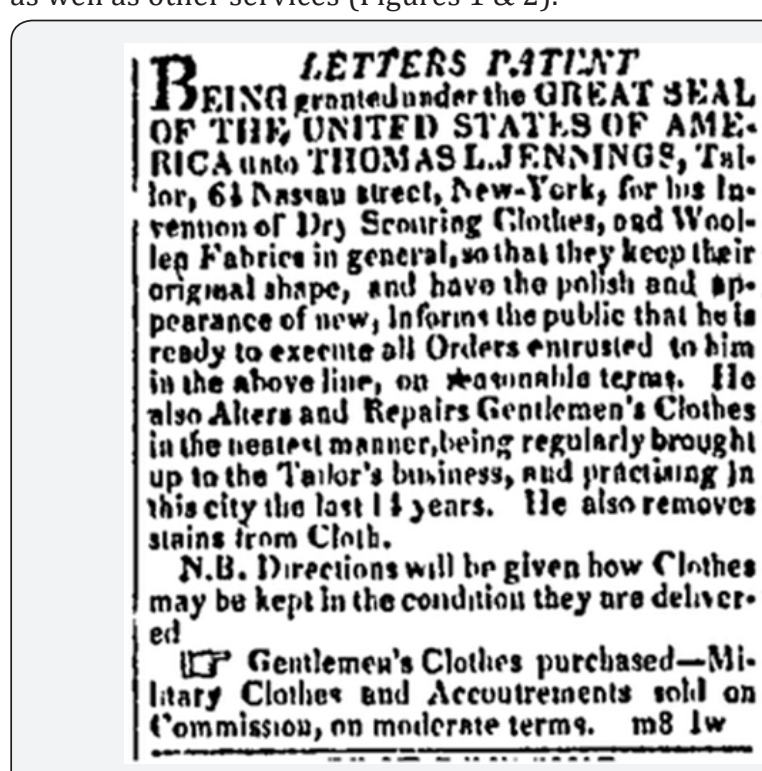

Figure 1: New York Gazette announcement on Thomas Jennings patent in March 13, 1821, ten days after USPTO's publication (in public domain).

\section{OFF-CAST CLOTHES WANTED.} At No. 64 Nassau Street, New-York. TT L. JENNiNGS, Patent Coat Scourer, iuforms 1. the gentlemen of this city that he purcbases the above articles, for which he will pay cash.

Those gentleinen whoplease to leave or sead their address will be immediately attended to. dec 22 I $w *$

Figure 2: The Evening Post announcement, on second-hand clothing purchase by Thomas Jennings, Wednesday, December 26,1821 , p. 3. (in public domain). 
For a long time, African-Americans were recognized only for their artistic talents, such as dance and music, and they were not allowed to possess inventive ingenuity in terms of engineering, to make discoveries or even present original technological or scientific proposals [5]. Jennings overcame these barriers by designing a major innovation at his time, hugely successful. As applicant, he became famous in his city proposing and dealing with such a new technology, a differential for tailoring services. This is a practice he must have obtained from a previous tailor from Manhattan, when too young. He probably used appropriated chemicals to remove difficult stains from clothing [5]. It was probably at the same time that he also offered himself to help and dig trenches to protect New York City from 1812 War invasions. Unfortunately, little is known about his life (Figure 3).

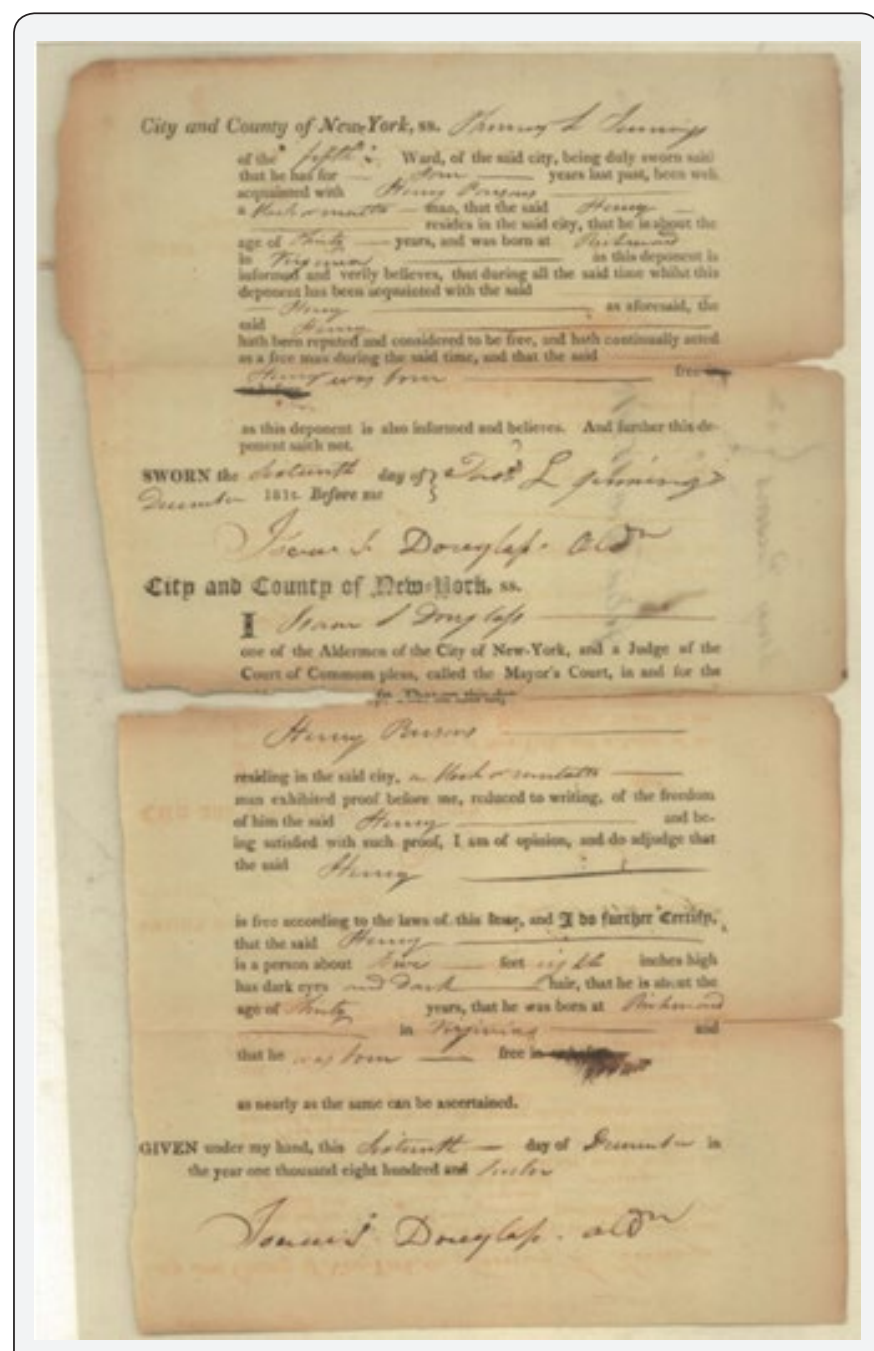

Figure 3: Writing with Thomas Jennings' signature on December 16, 1812, number MS 2085. Cortesy: The New York Historical Society - www.nyhistory.org (in public domain).

According to patent rules, there is no doubt about the originality of his invention. In fact, on March 12, 2014, the second section of the $113^{\text {th }}$ United States Congress passed a resolution recognizing Thomas Jennings as "the first African-American to have been granted a patent by the United States."
Jennings used his patent rights to promote social change for racial equality, thereby gaining fame, fortune, leadership, and prestige in the African-American community. One of his first actions was to obtain the freedom of his wife, Elizabeth Jennings (1798 - 1873). Jennings participated in each National Convention of the People of Colour and was also one of the administrators of the Abyssinian Baptist Church. He founded some philanthropic rights organizations, such as the New York African Society for Mutual Relief, and the Legal Rights Association, among others. He also aided in the publication of Freedom's Journal, the first weekly communication vehicle of this nature aimed at the socalled Afro-Americans, released on March 16, 1827.

As expected, the closest members of his family followed in his footsteps. Jennings' wife and daughters were active in the Ladies Literary Society of New York, an organization that raised funds for free slaves and promoted the rights of AfricanAmerican women.

One notable episode in US history occurred on Sunday, July 16, 1854, when Thomas' youngest daughter Elizabeth Jennings (later Graham, 1827-1901, Figure 4), an American teacher and activist, won an unprecedented court decision involving racial segregation [6]. She had insisted on her right to use a horsedrawn street car available from New York City at a time when all these companies were private and operated segregated cars. In fact, there were street cars only for whites and others for blacks, with inscriptions as: "Black People Allowed in This Car". After leaving a Church with a friend, the driver had forbidden Elizabeth from entering the street car (although this was quite empty), and as she had disobeyed, was forcibly removed from vehicle, even with the aid of a police officer who was nearby, in collaboration with some passengers. She was wounded, her hat still ruined and her dress torn [6].

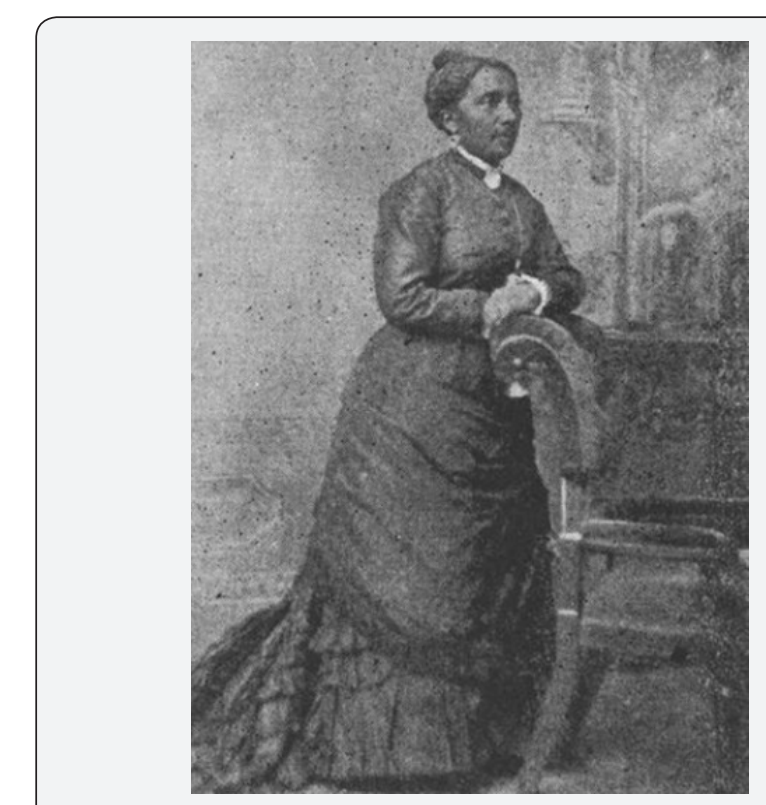

Figure 4: Elizabeth Jennings Graham (1827 - 1901), around 1895 (in public domain). 
With financial assistance from her father, Elizabeth was represented by the famous law firm of Culver, Parker and Arthur. More precisely, his case was defended by the young lawyer Chester Alan Arthur (1829 - 1886), who later became the $21^{\text {st }}$ President of the United States, from 1881 to 1885. His application was decided in the following year, initiating a powerful legal precedent. But it was only in the next decade that discrimination accesses to New York public transports stopped - much owed to similar legal questions, as well as the Emancipation Proclamation, that banned slavery in the United States.

Elizabeth also preceded in a century the famous discrimination case of the American seamstress Rosa Louise McCauley Parks (1913 - 2005), who refused to give up her place in the bus to a white, and since then it has been a civil movement activist, in legal rights. Finally, it should be noted that Elizabeth Jennings was also known for opening the first kindergarten school for black children in New York.
Freedom, even to innovate, was what Jennings and his daughter cried out for, fighting against slavery, the worst of humanity's inventions.

\section{References}

1. Khan BZ (2005) The Democratization of Invention: Patents and Copyrights in American Economic Development, 1790-1920. Cambridge University Press p. 322.

2. Yancy DC (1984) The Stuart Double Plow and Double Scraper: The Invention of a Slave. J Negro Hist 69(1): 48-52.

3. (2018) The United States Patent and Trademark Office.

4. (2018) Directory of American Tool and Machinery Patents.

5. Sluby PC (2011) The Entrepreneurial Spirit of African American Inventors. Praeger p. 250.

6. Greider K (2005) The Schoolteacher on the Streetcar. The New York Times.

\section{Your next submission with Juniper Publishers will reach you the below assets}

- Quality Editorial service

- Swift Peer Review

- Reprints availability

- E-prints Service

- Manuscript Podcast for convenient understanding

- Global attainment for your research

- Manuscript accessibility in different formats

( Pdf, E-pub, Full Text, Audio)

- Unceasing customer service

Track the below URL for one-step submission https://juniperpublishers.com/online-submission.php 